\title{
RECENT DISCOVERIES OF LARGE DIAMONDS IN TRINITY COUNTY, CALIFORNIA
}

\author{
By Rudolph W. Kopf, Cornelius S. Hurlbut, and John I. Koivula
}

\begin{abstract}
Although California has produced over 600 diamonds, some of which have been of gem quality, the largest until recently weighed approximately $6 \mathrm{ct}$. In the early 1980s, however, Edgar J. Clark found a 3.90ct stone; in 1987, he discovered three stones weighing $32.99,17.83$, and $14.33 \mathrm{ct}$. These four diamonds were recovered from stream gravels of Hayfork Creek in Trinity County, California. All four are of industrial grade and all have one interesting feature in common, that is, two generations of diamond growth. The initial crystal, or group of crystals, is encrusted by a later generation of diamond overgrowth that, although it conforms crystallographically to the underlying crystal, shows different crystal forms. This unusual feature, common to all four crystals, would indicate that they originated from the same source.
\end{abstract}

During the 1980s, Edgar J. Clark, a retired geologist and miner, recovered four large diamonds, three of record-breaking size, in northern California. According to Mr. Clark, all were found on Hayfork Creek, in the Trinity County portion of the Klamath Mountains. The first and smallest, found in the early 1980s, weighed $3.90 \mathrm{ct}$. Burton Westman, a consulting geologist in Boulder City, Nevada; examined the stone and confirmed its identity as diamond. Mr. Clark has since named the diamond "Jeopardy."

\section{ABOUT THE AUTHORS}

Mr. Koof is a consulting geologist in Grass Valley, California; Dr. Hurlbut is prolessor emeritus of mineralogy at Harvard University, Cambridge, Massachusetts; and Mr. Koivula is chief gemologist at the Gemological Institute of America, Santa Monica, Calitornia.

Acknowledgments: This study could not have been undertaken without the information kindly supplied by Edgar Clark and by his guidance in the field. Other residents of Trinity County, also of invaluable help, include Bertha Carlson and Mike MacDonald, who supplied intormation about personal finds, and James O'Donnell, who led a guided field trip. We are also indebted to Burton Westman of Boulder City, Nevada, for allowing us to study one of the diamonds.

Gems \& Gemology, Vol. 26, No. 3, pp. 212-219

(C) 1990 Gemological Institute of America
On January 4, 1987, while demonstrating the art of gold panning to a novice, Mr. Clark made his next find: a 14.33-ct diamond that, because of its accidental discovery, he named "Serendipity." Six months later, on June 12 , he recovered a third diamond, of 32.99 ct. Over twice the size of Serendipity, this exciting stone was dubbed "Doubledipity." Most recently, in September 1987, Mr. Clark found yet a fourth large diamond, a 17.83-ct stone that he named "Enigma." None of the four diamonds is of gem quality, but all have similar external characteristics. The specific gravities of all four stones, as determined by hydrostatic weighing, lie within $3.510 \pm 0.005$, which is typical for diamond. The diamonds are presently on loan to the Mineralogical Museum at Harvard University.

This article reports on an examination of these four diamonds and their significance both historically and geologically, especially with regard to the information they provide on the original source of diamonds found in this area.

\section{PREVIOUS DIAMOND DISCOVERIES IN CALIFORNIA}

More than 600 diamonds have been found in California since the first was discovered near Placerville, El Dorado County, in 1848 (Kopf, 1989). Most of these are very small, less than $1 \mathrm{ct}$, and only a few, like the 0.24 -ct octahedron shown in figure 1, are of gem quality. The most notable California diamonds are listed in table 1. Until Mr. Clark's discoveries in Trinity County, the largest diamond found in the state weighed approximately $6 \mathrm{ct}$ :

An anonymous item published in the Mining and Scientific Press ("Diamonds in Trinity Co., Cal.," 1871) reveals, however, that Mr. Clark may not have been the first to discover a large diamond in Trinity County. The entry describes the finding by I. Woodbury of a "queer looking pebble" while mining in the Weaverville area of Trinity County in the late 1860s. The stone was described as "having a glazed metallic coating. The crust was broken off on one side ... revealing the grain of the stone." Mr. Woodbury subsequently became con- 


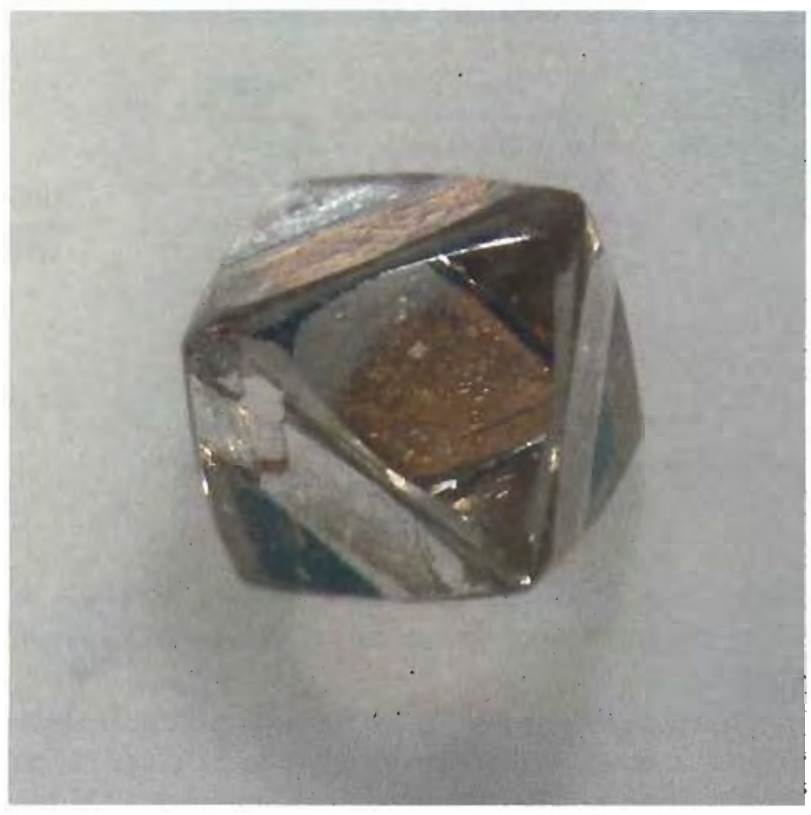

Figure 1. This 0.24-ct gem-quality diamond octahedron from Trinity County, California, was discovered as a by-product of gold panning in 1974. Photomicrograph by John I. Koivula.

$\therefore$

vinced that the stone, described as "half an inch or more in diameter," was a diamond. At that size, and assuming it was a diamond, it probably weighed between 10 and $15 \mathrm{ct}$. Unfortunately, the stone was subsequently lost. The significance of this report, however, will become apparent from the following descriptions of Mr. Clark's discoveries.

\section{THE FOUR LARGE TRINITY COUNTY DIAMONDS}

The four large diamonds found by Mr. Clark in Trinity County are described below and summarized in table 2 .

Jeopardy. The 3.90-ct diamond crystal that Mr. Clark first discovered measures $9.19 \times 8.36 \times$ $6.99 \mathrm{~mm}$ (figure 2). This diamond consists of two parts with different surface features. About twothirds of the crystal is encrusted with a yellowbrown semitranslucent to nearly opaque overgrowth that is inert to U.V. radiation. The other portion is yellow, translucent, and fluoresces a dull yellow to long-wave U.V. but does not phosphoresce.

Two surfaces of the encrusted portion are essentially square and at right angles to each other, while a small third surface is at right angles to them. This leads one to suspect that the underlying faces are cubic. Measurements made on a twocircle goniometer indicate that this is indeed the case, since not only were reflections from the overgrow th parallel to underlying "cubic" surfaces but reflections from tiny octahedral and dodecahedral surfaces were as well. The reflections

TABLE 1. The four largest authenticated California diamonds reported in the literature prior to 1980 (listed in order of decreasing weight).

\begin{tabular}{|c|c|c|c|c|c|}
\hline $\begin{array}{l}\text { Weight } \\
\text { given in } \\
\text { reference }\end{array}$ & $\begin{array}{l}\text { Weight } \\
\text { (in metric } \\
\text { carats) }\end{array}$ & $\begin{array}{l}\text { Year } \\
\text { found }\end{array}$ & Finder & Locality & Reference \\
\hline $6 \mathrm{ct}$ & $6 \pm$ & 1868 & John Moore & $\begin{array}{l}\text { Cherokee, Butte } \\
\text { Co. }\end{array}$ & Hill, 1972, p. 43 \\
\hline 0.53 grams & 2.65 & 1934 & Robert Echols & $\begin{array}{l}\text { Near Plymouth, } \\
\text { Amador Co. }\end{array}$ & $\begin{array}{l}\text { Sperisen, } 1938, \text { p. } 39 \\
\text { Woods, } 1986, \text { p. } 186\end{array}$ \\
\hline $71 / 4$ grains $^{a}$ & 2.3 & $\begin{array}{c}1867 \\
\text { or earlier }\end{array}$ & Unknown & $\begin{array}{l}\text { French Corral, } \\
\text { Nevada Co. }\end{array}$ & $\begin{array}{l}\text { Whitney (in Silliman, } \\
1867, \text { p. } 355 \text { ) }\end{array}$ \\
\hline $255 \mathrm{mg}$ & 1.28 & 1883 & George Evans & Amador Co. & $\begin{array}{l}\text { "Diamonds in } \\
\text { California," } 1959, \text { pp. } \\
\text { 26, 28; Hill, } 1972 \text {, p. } 41\end{array}$ \\
\hline \multicolumn{6}{|c|}{$\begin{array}{l}\text { aMany reports published during the last century state that the largest California diamond was found in } \\
\text { Fiench Corral, Nevada County, and report its weight between } 7 \text { and } 7.5 \mathrm{ct} \text {. In reality, the weight of the } \\
\text { stone was originally reported by Whitney (in Silliman, 1867) as } 71 / 4 \text { grains. The weight of the stone was } \\
\text { erroneously given by Kunz }(1885, p .730 \text { ) as } 7 \% \mathrm{ct} \text {, an error that has been perpeluated for over } 100 \text { years. } \\
\text { This error was discovered by one of the authors (RWK) in } 1988 \text { during a search of the literature. }\end{array}$} \\
\hline
\end{tabular}


TABLE 2. Comparison of large diamonds found by Edgar J. Clark in Trinity County, Calitornia. Listed in order of decreasing weight.

\begin{tabular}{|c|c|c|c|c|c|}
\hline Name & $\begin{array}{l}\text { Date of } \\
\text { find }\end{array}$ & $\begin{array}{l}\text { Weight } \\
\text { (ct) }\end{array}$ & $\begin{array}{l}\text { Measurements } \\
(\mathrm{mm})\end{array}$ & Color & Surface \\
\hline Doubledipity & June 1987 & 32.99 & $21.27 \times 15.10 \times 14.76$ & $\begin{array}{l}\text { Moderate yellowish } \\
\text { brown }\end{array}$ & $\begin{array}{l}\text { Rough, } \\
\text { encrusted }\end{array}$ \\
\hline Enigma & September 1987 & 17.83 & $19.72 \times 15.33 \times 9.95$ & Grayish brown & $\begin{array}{l}\text { Rough, } \\
\text { encrusted }\end{array}$ \\
\hline Serendipity & January 1987 & 14.33 & $16.25 \times 12.64 \times 10.60$ & $\begin{array}{l}\text { Pale grayish olive } \\
\text { green }\end{array}$ & $\begin{array}{l}\text { Rough, } \\
\text { encrusted }\end{array}$ \\
\hline Jeopardy & 1982 or 1983 & 3.90 & $9.19 \times 8.36 \times 6.99$ & Yellow-brown & $\begin{array}{l}\text { Rough, } \\
\text { partially } \\
\text { encrusted }\end{array}$ \\
\hline
\end{tabular}

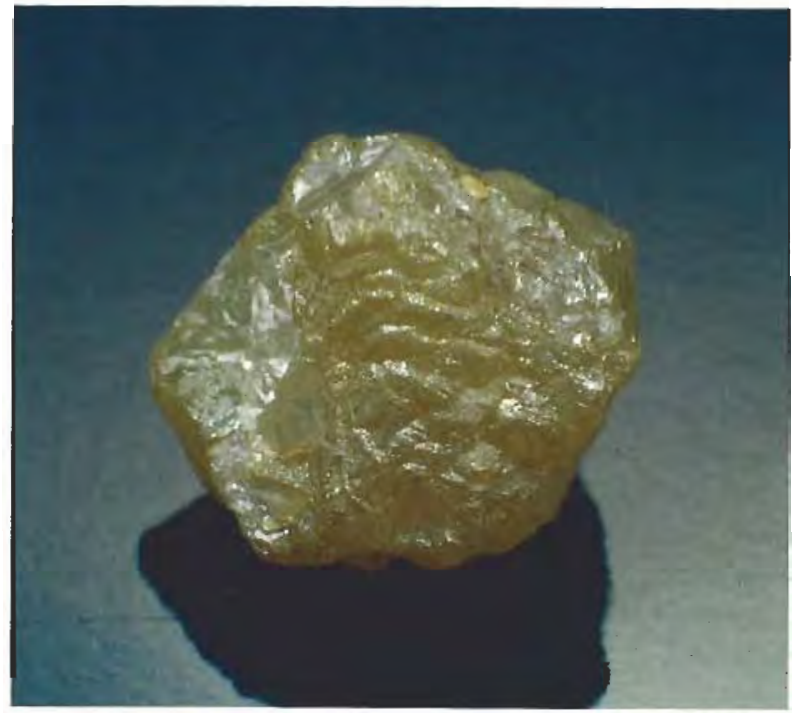

Figure 2. The 3.90-ct crystal subsequently named leopardy is the first of four large rough California diamonds discovered by Edgar Clark in Trinity County in the 1980s. Photo by Robert Weldon.

from a given crystal form were not from a welldefined face but were seen at the same angular position as many points of light from the irregular overgrowth. *

The portion of the stone with no overgrowth has no well-defined crystal faces, but reflections from small areas show that it and the overgrown portion have a parallel crystallographic orientation. At the junction of the two different-appearing parts, the overgrowth terminates with no indication of fracturing.

Serendipity. Mr. Clark's identification of this 14.33-ct pebble as a diamond was verified at the
GIA Gem Trade Laboratory in Santa Monica. A brief description of the stone was given in Koivula (1987).

Serendipity is pale grayish olive green. It fluoresces a weak brown to long-wave U.V. radiation and a weak reddish brown to short-wave U.V. No phosphorescence was observed in either situation.

Macroscopically, this diamond is semitranslucent with an almost greasy adamantine luster (figure 3). At first glance, it appears to be composed of a number of irregular nodular masses with a rough surface and no obvious crystal form. On closer inspection, however, one can discern that the bulk of the specimen is composed of at least seven randomly intergrown cubes, the largest of which is about $5 \mathrm{~mm}$ on an edge. The rough surfaces and rounded edges and corners of the cubes are the result of an irregularly distributed overgrowth of diamond that tends to obscure the cubic form of the underlying diamond crystals. There is no direct means to measure the thickness of the overgrow th. However, since the cubic nature

\footnotetext{
*The two-circle optical goniometer is an instrument used to measure crystal angles. A collimated light beam is reflected from successive faces as the crystal is turned. The reflections are observed through a telescope and the angles of reflection read from two graduated circles. The crystal form of the specimen can then be identified from the known angular positions of the faces. For the present study, the diamond specimens were mounted on the goniometer so that what appeared to be underlying cube faces were in positions to reflect the light beam. By rotating on both vertical and horizontal axes of the instrument, all faces (on the upper half of the crystal) were brought into positions to reflect. In these diamonds, the tiny faces of a given crystal form on the crys talline overgrowth all reflect simultaneously at angles consistent with those of single isometric crystals and conform crystallographically to the underlying cubes. Were the overgrowths polycrystalline aggregates, the reflections from the faces of the encrusting crystals would be random.
} 


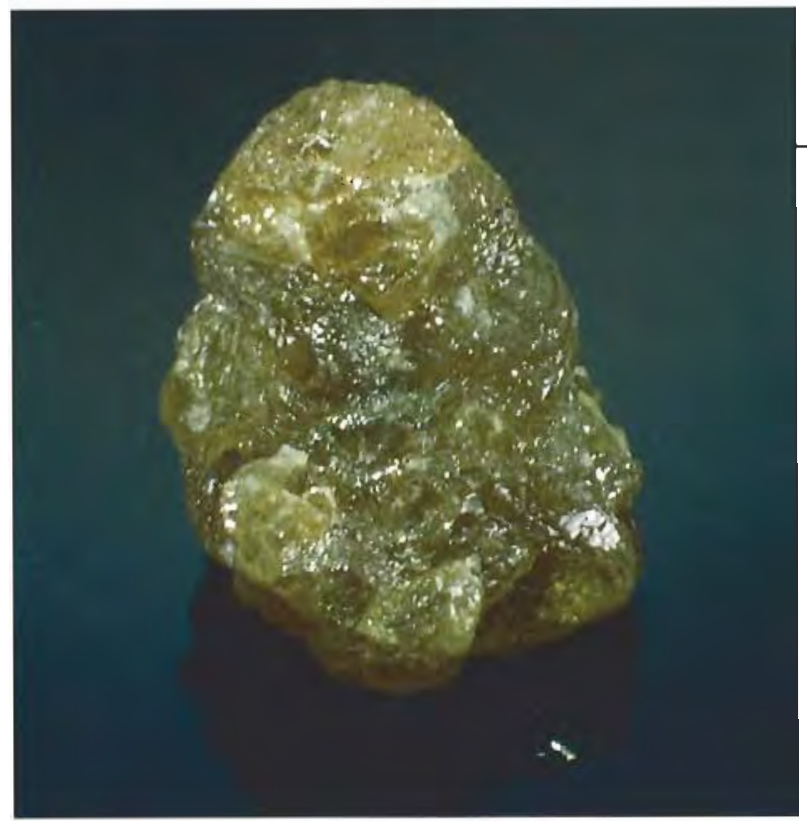

Figure 3. With a weight of $14.33 \mathrm{ct}$, Serendipity is the third largest diamond found to date in the state of California. Photo by Robert Weldon.

of the primary crystals in this diamond is less evident than in the 3.90-ct stone, it is presumed that the overgrowth is thicker, and possibly as thick as $2-\mathrm{mm}$. When viewed in reflected light, the overgrowth gives reflections from a multitude of tiny, step-like crystal faces. Measurement on the two-circle goniometer showed that all faces of the overgrowth on a single "cube" have common angles of reflection, those of the octahedron.

Doubledipity. This diamond, the largest yet to be reported from California, is approximately $33 \mathrm{ct}$ (32.99) and measures $21.27 \times 15.10 \times 14.76 \mathrm{~mm}$ (figure 4). It is a moderate yellowish brown but lacks the adamantine luster usually associated with diamond. It is opaque except on the edges, where it is translucent, and does not fluoresce to either long- or short-wave U.V. radiation.

Examination of the stone shows that it is composed essentially of seven interpenetrating cubes that are in random crystallographic orientation to one another. The bulk of the aggregate comprises three cubes of nearly equal size (10.0 to $10.6 \mathrm{~mm}$ on an edge). Four smaller cubes are about $5 \mathrm{~mm}$ on an edge. The cuboid surfaces are, with the exception of one small area, completely encrusted with an overgrowth of small diamond crystals. Because of the larger size of the primary crystals and, presumably, a thinner and more uniform secondary overgrowth, their cubic habit is more obvious than in the 14.33-ct stone (Serendipity). The corners and edges of the stone's surface are rounded by the overgrowth. When the diamond is examined in reflected light with both the microscope and the two-circle goniometer, there is no reflection from the faces of the cubes, but brilliant reflections do occur from their corners (the octahedron). Other reflections, as in the 14.33-ct stone, are not from single faces but are from a myriad of tiny surfaces of parallel octahedral faces. Thus, the secondary coating of this stone, too, consists of a parallel growth of octahedral crystals conforming crystallographically to the underlying cubes.

The encrusting overgrowth on one of the large cubes is locally absent and forms a depression, about $6 \times 7 \mathrm{~mm}$, where three nearly plane surfaces intersect at a common point. The angles between these intersecting planes, measured on a wax impression of the cavity, are $120^{\circ}$, the angles of the dodecahedron. From this we infer that a dodecahedral crystal, which had grown either before or contemporaneously with the diamond cubes, had separated from the cluster after the diamond became encrusted. Since the core of the diamond aggregate is composed of crystals with a cubic habit, the faced cavity probably resulted from the displacement of a different mineral with different crystal form, possibly a garnet. At the edges of this cavity, the encrustation can be observed to be approximately $0.5-1.0 \mathrm{~mm}$ thick.

In two areas (the larger about $2 \times 3 \mathrm{~mm}$ ) on the surface of Doubledipity, the encrusting diamond appears to be underlain by fractures that partially separate the crust from the main mass. The fact

Figure 4. At $32.99 \mathrm{ct}$, Doubledipity is the largest diamond yet recovered in California. Photo by Robert Weldon.




that these areas are yellow suggests that the entire aggregate may be yellow and appears brown because of its greater thickness.

Enigma. Mr. Clark's latest find is a 17.83-ct tabular stone that is roughly in the shape of an equilateral triangle. It is grayish brown and semitranslucent to opaque (figure 5). Microscopic black specks scattered throughout the specimen contribute to the grayish appearance. The broad surfaces are encrusted with a diamond overgrowth that is finegrained and regular on one side. On the opposite side, a small area has a similar overgrowth made up primarily of overlapping hummocks rising about $4 \mathrm{~mm}$ above the essentially planar surface. Two of the bounding edges of the triangular stone are cleavage surfaces, which indicates that the stone was originally larger. When the stone was exposed to short-wave U.V. radiation, the cleavage surfaces fluoresced yellow, the encrustation brown; but to long-wave U.V., all parts of the stone fluoresced a brilliant yellow. There was no phosphorescence.

The triangular shape suggests that, before the overgrowth, the stone was an octahedron flattened on an octahedral face. The angular relationship of the relatively flat triangular surface to the octahedral cleavages supports this hypothesis. The surface of the overgrowth is a multitude of tiny crystal faces, many unidentified. But, assuming that the overgrowth conforms crystallographically to the underlying crystal, the strongest reflections

Figure 5. The 17.83-ct stone called Enigma is the most recent large diamond discovered in California. Photo by Robert Weldon.

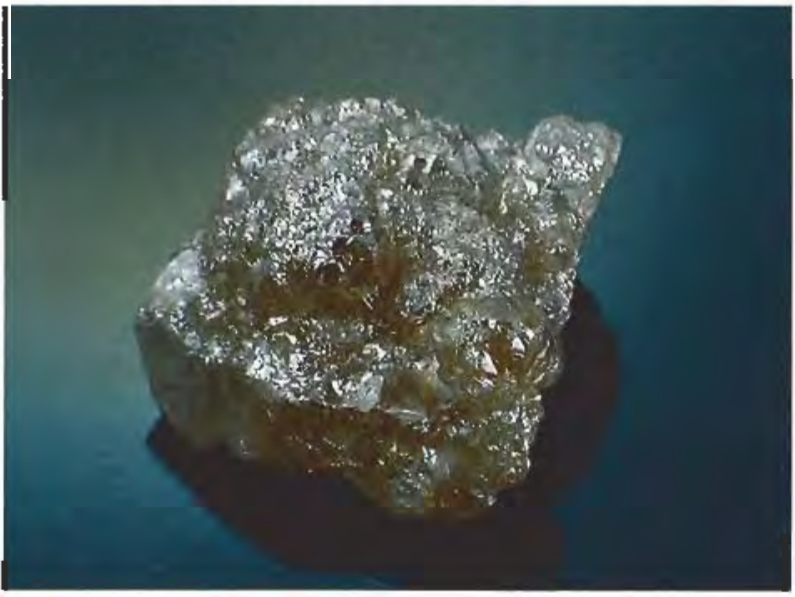

are from the octahedron and the cube. The most impressive evidence that the two generations of diamond are in parallel position is that the cleavage surfaces pass uninterrupted through both the original crystal and the encrusting hummocks.

The cleavage surfaces are not single planes but are composed of a mosaic of small surfaces $0.5-3$ $\mathrm{mm}^{2}$, each of which is disoriented $1^{\circ}-2^{\circ}$ with respect to its neighbors. This shows that the original crystal, and probably the overgrowth as well, is made up of many small subparallel crystalline units. An unresolved problem presented by the two bounding cleavages is that they are at $60^{\circ}$ to one another rather than at $90^{\circ}$, as they should be for a single crystal. This suggests that the stone is twinned with one cleavage belonging to each of the two individuals, but the overgrow th prevents location of the twin plane.

\section{SOURCE}

Many early published reports of California diamonds note the presence of microscopic diamonds in black sand in the Trinity River. Inasmuch as the river flows through both Trinity and Humboldt Counties, it is not readily apparent which county or counties yielded these historic diamonds. Sperisen $(1938$, p. 40) reported that they were in the Trinity County portion, whereas Hanks (1870, p. 162) cited the lower Trinity River, considered by later compilers to have been in Trinity County, as the source. Originally part of Trinity County in 1850, however, the lower Trinity River region was reassigned to northern Humboldt when that county was created in 1853 (Beck and Haase, 1974, p. 62). Murdoch and Webb (1948, p. 131) describe the Trinity County (actually Humboldt County) diamonds as "many" and "minute," yet MacFall (1963, p. 94) cites Joseph Murdoch as the source of a report of a 2-ct diamond found near the junction of the Trinity and Klamath Rivers in Trinity County.

The four large stones found by Mr. Clark were recovered from auriferous sand and gravel on Hayfork Creek (figure 6), a tributary of the south fork of the Trinity River in Trinity County. Recently, a number of minute transparent stones have also been recovered from this area, specifically, from auriferous sand and gravel on Hayfork Creek (E. J. Clark and B. Carlson, pers. comms., 1987); on the east fork of the Trinity River at Helena (M. MacDonald, pers. comm., 1988); on Canyon Creek (E. J. Clark, pers. comm., 1987); and 




on other tributaries of the Trinity River in Trinity County (figure 7).

Hayfork Creek has yielded not only the largest diamonds found in the western United States but also considerable quantities of coarse-grained platinum-group metals. In fact, it was the principal source of the nation's platinum production around the turn of the century (Day, 1898).

Hershey (1902) described five isolated erosional remnants of Early Cretaceous strata in the Hayfork-Weaverville area of Trinity County. These
Figure 6. Four large diamonds have been found in Trinity County in northern California, along Hayfork Creek, a tributary of the Trinity River. Artwork by Carol Winkler; geology based on Irwin (1972). rocks have subsequently been designated part of the Great Valley sequence (Irwin, 1963, 1974, 1985; Jones and Irwin, 1971; and Irwin et al., 1974, 1985). The basal portion of these outliers is overlain by marine conglomerate rich in well-rounded and well-sorted quartz pebbles and contains placer gold (Hershey, 1902, p. 36). Interestingly, the diamonds found by Mr. Clark and Mr. MacDonald were recovered near or downstream from such Cretaceous erosional outliers. This suggests that the Cretaceous conglomerate is a secondary source 




Figure 7. This is a downstream view of Hayfork Creek in Trinity County, northern California, a typical stream in the Klamath Mountains. Diamonds, including the four large stones described here, as well as gold, platinum, and chromite, have been recovered from this creek. The largest stream boulders are about $3 \mathrm{~m}$ across and consist mainly of Mesozoic mafic volcanic rocks. Here, the stream flows over the Triassic and Jurassic Rattlesnake Creek terrane of Irwin (1985). Photo by Rudolph W. Kopf.

of the placer diamonds in Trinity County. According to this interpretation, the age of the lode or lodes must be Early Cretaceous or older.

Another method of locating the diamond lode(s) is to determine the source of anomalous minerals associated with the placer diamonds. Gold appears to have been derived from goldbearing quartz veins, and chromite and platinumgroup minerals from podiform chromite deposits in the ultramafic portion of ophiolite complexes in the western Paleozoic and Triassic terrane (Irwin, 1972; Page et al., 1986). Mr. Clark (pers. comm., 1990) reports having recognized chrome diopside, rare crystals of highly rounded pyrope, and possibly perovskite from heavy mineral concentrates in placers in the drainage of the Trinity River in Trinity County.

This coarse-grained placer mineral assemblage appears to occur sporadically in an arc-shaped north-trending belt that extends from Trinity County northward into Josephine County, Oregon. On the basis of available data, diamonds in Trinity County appear to have originated from this belt, here termed the Klamath Mountains diamond belt, which seems to coincide largely with the western Paleozoic and Triassic terrane or subprovince of Irwin (1974) and Ando et al. (1983), although other more distant source rocks cannot yet be ruled out.

\section{CONCLUSION}

The four record-sized California diamonds described herein have an unusual feature in common, that is, a coarsely crystallized core encrusted with a fine-grained diamond overgrowth. In all of the cases, the overgrowth conforms crystal- 
lographically to the underlying crystal. This would indicate that the four diamonds underwent the same physicochemical changes during crystal. lization and thus came from a common source. Although diamond aggregates are common, aggregates of cubic diamond crystals with octahedral overgrowths such as the 14.33-ct (Serendipity) and 32.99-ct (Doubledipity) stones reported here may be unique to this locality. The account of Mr. Woodbury's 1860 s find suggests that his stone was a similarly encrusted diamond and, further, that the larger diamonds of Trinity County are typically encrusted.

Gem and mineral prospectors in California and Oregon are encouraged to carefully examine their heavy mineral concentrates for diamonds. Moreover, those in Trinity County should watch for pale-colored, semitranslucent, rounded pebbles having a high luster and a rough surface. Such stones may also be diamond.

\section{REFERENCES}

Ando C.J., Irwin W.P., Jones D.L., Saleeby J.B. (1983) The ophiolitic North Fork terrane in the Salmon River region, central Klamath Mountains, California. Geological Society of America Bulletin, Vol. 94, pp. 236-252.

Beck W.A., Haase Y.D. \{1974\} Historical Atlas of California. University of Oklahoma Press, Norman, OK

Day D.T. (1898) Platinum. In D. T. Day, Ed., Mineral Resources of the United States for the Year 1897, 19th annual report of the United States Geological Survey to the Secretary of the Interior, 1897-98, Part VI (continued). Nonmetallic products, except coal and coke, p. 706.

Diamonds in:California (1959) Pages of History, Sausalito, CA, p. 57.

Diamonds in Trinity Co., Cal. (1871) Mining and Scientific Press, Vol. 22, p. 140.

Hanks H.G. (1870) Diamonds in California. Mining and Scientific Press, Vol. 20 p. 162.

Hershey O.H. (1902) The significance of certain Cretaceous outliers in the Klamath region, California. American Journal of Science, 4th series, Vol. 14, No. 79, pp. 33-37.

Hill M. (1972) Hunting Diamonds in California. Naturegraph Publishers, Healdsburg, CA.

Irwin W.P. (1963) Preliminary geologic map of the Weaverville quadrangle, California. U.S. Geological Survey Mineral Investigations Field Studies, Map MF-275.

Irwin W.P. (1972) Terranes of the western Paleozoic and Triassic belt of the southern Klamath Mountains, California. U.S Geological Survey Professional Paper 800-C, pp. C103-C111.

lrwin W.P. (1974) Reconnaissance geologic map of the Hayfork quadrangle, Trinity County, California. U.S. Geological Survey Miscellaneous Field Studies, Map MF-576.

Irwin W.P. (1985) Reconnaissance geologic map of the Hyampom quadrangle, Trinity County, California. U.S. Geological Survey Miscellaneous Field Studies, Map MF-1809.
Irwin W.P., Wolfe E.W., Blake M.C. Jr., Cunningham C.G. Ir (1974) Geologic map of the Pickett Peak quadrangle, Trinity County, California. U.S. Geological Survey Geologic Quadrangle, Map GQ-1111.

Irwin W.P., Yule J.D., Court B.L., Snoke A.W., Stern L.A., Copeland W.B. (1985) Reconnaissance geologic map of the Dubukella Mountain quadrangle, Trinity, Shasta, and Tehema Counties, California. U.S. Geological Survey Miscellaneous Field Studies, Map MF-1808.

Jones D.L., lrwin W.P. (1971) Structural implications of an offset Early Cretaceous shoreline in northern California. Geological Society of America Bulletin, Vol. 82, pp. 815-822.

Koivula J.I. (1987) Gem news: Largest California diamond found. Gems \&) Gemology, Vol. 23, No. 2, pp. 122-123.

Kopf R.W. (1989) First diamond find in California - When and where? California Geology, Vol. 42, No. 7, pp. 160-162.

Kunz G.F. (1885) Precious stones. In A. Williams, Jr., Ed,, Mineral Resources of the United States for the Calendar Years 1883 and 1884, U.S. Geological Survey, pp. 723-782.

MacFall R.P. (1963) Gem Hunter's Guide, rev. ed. Thomas Y. Crowell Co., New York.

Murdoch J., Webb R.W. $(194 \overline{8})$ Minerals of California. California Division of Mines Bulletin 136, pp. 129-132.

Page N.J, Singer D.A., Moring B.C., Carlson C.A., McDade J.M., Wilson S.A. (1986) Platinum-group element resources in podiform chromitites from California and Oregon. Economic Geology, Vol. 81, pp. 1261-1271.

Silliman B. (1867) Notice of new localities of diamonds in California. California Academy of Natural Sciences, Proceedings, Vol. 3, pp. 354-355.

Sperisen F.J. (1938) Gem minerals of California. California Journal of Mines and Geology, Vol. 34, No. 1, pp. 34-78.

Woods M.C. (1986) Diamond finds in California. California Geology, Vol. 39, No. 8, pp. 186-187. 